\title{
Quantification of Vibrio parahaemolyticus, Vibrio vulnificus and Vibrio cholerae in French Mediterranean coastal lagoons
}

\author{
Franck Cantet ${ }^{\mathrm{a}, 1}$, Dominique Hervio-Heath ${ }^{\mathrm{b}, 1}$, Audrey Caro ${ }^{\mathrm{a}}$, Cécile Le Mennec ${ }^{\mathrm{b}}$, Caroline Monteil ${ }^{\mathrm{a}}$, \\ Catherine Quéméréc ${ }^{c}$, Anne Jolivet-Gougeon ${ }^{c}$, Rita R. Colwell ${ }^{d}$, Patrick Monfort ${ }^{a, *}$
}

\footnotetext{
a "Ecologie des Systèmes Marins Côtiers", UMR 5119 CNRS, IRD, Ifremer, Université Montpellier 2 \& 1, Case 093, 34095 Montpellier Cedex 05, France

${ }^{\mathrm{b}}$ Ifremer, RBE, EMP, Laboratoire de Microbiologie-LNR, BP 70, 29280 Plouzané, France

${ }^{\mathrm{c}}$ UPRES-EA 1254 Microbiologie, Université Rennes 1, 35000 Rennes, France

d 3103 Biomolecular Sciences Building, Center for Bioinformatics and Computational Biology, Institute for Advanced Computer Studies, University of Maryland, College Park, MD 20742, USA

${ }^{1}$ F. Cantet and D. Hervio-Heath contributed equally to this work.

*: Corresponding author : Patrick Monfort, tel.: +33467144822 ; fax: +33467143719 ; email address : pmonfort@univ-montp2.fr
}

\begin{abstract}
:
Vibrio parahaemolyticus, Vibrio vulnificus and Vibrio cholerae are human pathogens. Little is known about these Vibrio spp. in the coastal lagoons of France. The purpose of this study was to investigate their incidence in water, shellfish and sediment of three French Mediterranean coastal lagoons using the most probable number-polymerase chain reaction (MPN-PCR). In summer, the total number of $V$. parahaemolyticus in water, sediment, mussels and clams collected from the three lagoons varied from 1 to $>1.1 \times 10^{3} \mathrm{MPN} / \mathrm{l}, 0.09$ to $1.1 \times 10^{3} \mathrm{MPN} / \mathrm{ml}, 9$ to $210 \mathrm{MPN} / \mathrm{g}$ and 1.5 to $2.1 \mathrm{MPN} / \mathrm{g}$, respectively. In winter, all samples except mussels contained $V$. parahaemolyticus, but at very low concentrations. Pathogenic (tdh- or trh2-positive) V. parahaemolyticus were present in water, sediment and shellfish samples collected from these lagoons. The number of $V$. vulnificus in water, sediment and shellfish samples ranged from 1 to $1.1 \times 10^{3} \mathrm{MPN} / \mathrm{l}, 0.07$ to $110 \mathrm{MPN} / \mathrm{ml}$ and 0.04 to $15 \mathrm{MPN} / \mathrm{g}$, respectively, during summer. V. vulnificus was not detected during winter. V. cholerae was rarely detected in water and sediment during summer. In summary, results of this study highlight the finding that the three human pathogenic Vibrio spp. are present in the lagoons and constitute a potential public health hazard.
\end{abstract}

Keywords : Vibrio ; Lagoons ; Shellfish ; Water ; Sediment ; Human pathogen 


\section{Introduction}

Vibrio spp. are autochthonous to marine and estuarine environments, and are components of those ecosystems (Colwell et al., 1977). However, some Vibrio species are also human pathogens. Vibrio parahaemolyticus is recognized throughout the world as the leading causal agent of human gastroenteritis resulting from consumption of raw seafood. Enteropathogenic strains of $V$. parahaemolyticus generally produce a thermostable direct hemolysin (TDH) and/or a TDH-related hemolysin (TRH). The genes $t d h$ and trh code for TDH and TRH, respectively (Iida et al., 2006). In the United States, V. vulnificus is responsible for 95 percent of all seafood-related deaths related to the ingestion of raw or undercooked seafood. Moreover, V. vulnificus has often been associated with serious infections caused by exposure of skin wounds to seawater. Different factors have been implicated in virulence of $V$. vulnificus including the $v v h A$ gene that encodes hemolytic cytolysin (Oliver, 2006). Vibrio cholerae, the causative agent of cholera, has been detected in natural fresh and brackish waters worldwide. This species has also been isolated from areas where no clinical cases of cholera have been reported (Colwell et al., 1977). However, most environmental isolates are $V$. cholerae non-O1/non-O139 capable of causing diarrheal outbreaks locally (Rippey, 1994).

Vibrios are responsible for many human cases of seafood-borne illness in many Asian countries and the United States (Rippey, 1994; Daniels et al., 2000; Su and Liu, 2007). The occurrence of potentially pathogenic Vibrio spp. in coastal waters and shellfish of European countries has already been documented, i.e., in Italy, Spain, and France (Barbieri et al., 1999; Martinez-Urtaza et al., 2008; Hervio-Heath et al., 2002). Some non-cholera Vibrio outbreaks have also been described in these countries. However, vibrios are rarely responsible for severe outbreaks in Europe but instead for incidence of vibriosis (Geneste et al., 2000). In France, one hundred cases of $V$. parahaemolyticus infection were reported in 2001, all of which involved consumption of mussels imported from Ireland (Hervio-Heath et al., 2005). Since then, however, only sporadic cases of $V$. parahaemolyticus infections have been reported (Quilici et al., 2005).

The coastal lagoons of Southern France (Mediterranean) are ecosystems that receive inputs from watersheds and exchanges with the sea and are thus characterized by significant variation in water temperature and salinity. The coastal area and lagoons, especially Thau, the largest lagoon, are sites of significant shellfish production. Vibrio parahaemolyticus, $V$. vulnificus, and V. cholerae non-O1/non-O139 were isolated in coastal water and mussel samples collected offshore near the lagoons (Hervio-Heath et al, 2002). Two cases of 
83 infection involving Vibrio spp. have been reported in the south of France. The death in 1994

84 of an immuno-compromised patient was caused by an infection by $V$. cholerae non-O1/non85 O139 after exposure of skin wounds to seawater (Aubert et al., 2001). In 2008, a fisherman 86 was infected by V. vulnificus after a skin injury came into contact with brackish water from 87 the Vic lagoon, in Southern France. This victim, weakened by both kidney and lung failure, 88 died as a result of sepsis (Personal communication).

89 The presence of pathogenic vibrios in these lagoons represents a potential public 90 health threat. To evaluate public health risk, data on the prevalence, distribution, and 91 virulence of these bacteria are needed.

92 In this study, the occurrence and abundance of three human pathogenic Vibrio species 93 (V. parahaemolyticus, V. vulnificus and V. cholerae) were investigated in water, shellfish, and 94 sediment samples collected from three coastal Mediterranean lagoons during summer and 95 winter seasons of 2006 and 2007. To our knowledge, this report represents the first detection 96 and quantification of these three Vibrio species simultaneously in water, shellfish, and 97 sediment of a lagoon ecosystem. 


\section{Materials and methods}

\subsection{Sampling sites}

Figure 1 shows the location of sampling sites included in this study: Thau, Prévost, and Mauguio, three lagoons on the French Mediterranean coast (Languedoc area). These lagoons were selected on the basis of fishery and recreational activities that take place there. The Thau lagoon is of economical importance due to its large-scale bivalve mollusk farming (approximately 15,000 t of mussels and oysters produced each year), surface area of $75 \mathrm{~km}^{2}$, and mean depth of $5 \mathrm{~m}$. Small-scale recreational activities (bathing and sailing) also take place in this lagoon. The Prévost lagoon $\left(29 \mathrm{~km}^{2}, 0.8 \mathrm{~m}\right.$ mean depth) sustains a small shellfish (mussels) production capacity. Unlike the Thau and Prévost lagoons, each of which has salinity similar to seawater, the Mauguio lagoon, with a controlled seawater entry, displays a significantly lower salinity (31.7 km², 0.8 m mean depth).

\subsection{Sample collection and processing}

Surface water (5l) and sediment (five $800 \mathrm{~cm}^{3}$ cores) samples were collected in September, 2006, and January and June, 2007, at one site in each lagoon (Thau: N 43²3'35.8', E 003³7'20.8'’; Prévost: N 43³1'16.6’', E 00354'03.1'’; and Mauguio: N 43³5'09.5’', E 00401'15.4'”) along with mussels (Mytilus galloprovincialis, 20-30 per sample) from the Thau and Prévost lagoons and clams (Ruditapes decussatus, 30-40 per sample) from the Thau lagoon. Water temperature and salinity were recorded simultaneously at the time of sampling at each site. Environmental samples were transported in coolers (12$15^{\circ} \mathrm{C}$ ) to the laboratory and processed within 4 hours of collection.

\subsection{Quantification of V. parahaemolyticus, V. vulnificus and V. cholerae by MPN-PCR}

A combined Most Probable Number-Polymerase Chain Reaction (MPN-PCR) method (Luan et al., 2008) was applied to detect and enumerate $V$. parahaemolyticus, V. vulnificus and $V$. cholerae in the environmental samples. Quantification of the vibrios was achieved by enrichment in alkaline peptone water (APW), following application of the Most Probable Number method. Growth of the Vibrio species in APW broth was confirmed by PCR and enteropathogenic $V$. parahaemolyticus ( $t d h$ positive and trh2 positive) by real-time PCR. 
132 Water samples (1, 10, $100 \mathrm{ml}$ and $1 \mathrm{l})$ were filtered, in triplicate, through $0.45 \mu \mathrm{m}$ pore size membranes (nitrocellulose, Whatman, GE healthcare, Versailles, France) and the filters were incubated in APW at $41{ }^{\circ} \mathrm{C}$ for $24 \mathrm{~h}$. Superficial sediment samples collected from the first three centimeters of five cores were mixed thoroughly and flesh and intra-valvular liquid of mussels and clams (shellfish tissue) were each homogenized. From the preparations of sediment or shellfish, $10 \mathrm{ml}$ and $1 \mathrm{ml}$ of serial 10 -fold dilutions were inoculated in triplicate into APW broth and incubated at $41{ }^{\circ} \mathrm{C}$ for $24 \mathrm{~h}$.

After enrichment, bacterial DNA was extracted from $1 \mathrm{ml}$ of the APW using the Wizard Genomic DNA Purification kit (Promega, Charbonnières, France) designed for Gramnegative bacteria. Three primer pairs, based on the toxR and $v v h A$ genes, and a portion of the Intergenic Spacer Region (ISR) 16S-23S rRNA were used to detect V. parahaemolyticus, V. vulnificus and $V$. cholerae, respectively (Table 1). PCR amplification included an initial denaturation at $94{ }^{\circ} \mathrm{C}$ for $2 \mathrm{~min}, 35$ cycles of denaturation at $94{ }^{\circ} \mathrm{C}$ for $30 \mathrm{~s}$, primer annealing at $57{ }^{\circ} \mathrm{C}$ for $30 \mathrm{~s}$, and extension at $72{ }^{\circ} \mathrm{C}$ for $30 \mathrm{~s}$, and final extension at $72{ }^{\circ} \mathrm{C}$ for $8 \mathrm{~min}$.

This protocol was performed in an Eppendorf Mastercycler (Eppendorf, Le Pecq, France) and optimized in a $25 \mu \mathrm{l}$ reaction containing $5 \mu \mathrm{l}$ of $5 \mathrm{X}$ buffer (Promega, Charbonnières, France), $0.5 \mu \mathrm{l}$ of dNTPs $(200 \mu \mathrm{M}), 0.25 \mu \mathrm{l}$ of each primer $(25 \mu \mathrm{M})$ (Invitrogen, Cergy pontoise, France), $13.9 \mu \mathrm{l}$ of ultrapure water (Millipore SAS, Molsheim, France), $5 \mu \mathrm{l}$ of target DNA (undiluted, diluted 1/10 and 1/100), $0.1 \mu \mathrm{l}$ GoTaq DNA polymerase ( $5 \mathrm{U} / \mu \mathrm{l}$, Promega, Charbonnières, France), $1 \mathrm{mg} / \mathrm{ml}$ of BSA (Sigma-Aldrich Chimie SARL, Saint Quentin Fallavier, France). The PCR-amplified DNA products were separated on a 1.2\% agarose gel in Tris-Borate ETDA (TBE) buffer $\mathrm{pH} 8.3$ (Invitrogen, Cergy pontoise, France), at $100 \mathrm{~V}$ for $30 \mathrm{~min}$ with a 1-Kb Plus DNA Ladder (Invitrogen, Cergy pontoise, France) and revealed with ethidium bromide $(0.5 \mathrm{mg} / \mathrm{ml})$.

MPN values were calculated from the statistical tables of De Man and expressed as MPN per liter, MPN per milliliter, and MPN per gram, for water, sediment, and shellfish tissue samples, respectively.

\subsection{Quantification of tdh + and trh2+ V. parahaemolyticus by MPN-real-time PCR}

Vibrio parahaemolyticus (toxR) positive enrichment cultures were further characterized by real-time PCR (TAQMAN probe, Eurogentec, Seraing, Belgique) for presence of virulence-associated genes, $t d h$ and $t d h$-related hemolysin, trh2, found in enteropathogenic $V$. parahaemolyticus. Primers and probes for $t d h$ and trh2 genes selected for 
166 real time PCR assay were designed based on the sequences of a 269bp- and 500bp-region of 167 the two genes, respectively, using primers from Bej et al. (1999). Sequence data are available 168 on Genbank under accession numbers AF378099 and AY034609 for tdh and trh2, 169 respectively. The real-time PCR systems developed for these two genes exhibited positive 170 amplification on 8 clinical and 30 environmental $V$. parahaemolyticus strains. TaqMan PCR 171 using $t d h$ and trh2 primers and probes on 50 other bacterial isolates belonging to the Vibrio 172 genus ( $V$. vulnificus, $V$. cholerae, $V$. alginolyticus, $V$. mimicus) and to other genera 173 (Aeromonas, Listonella, Citrobacter, Proteus, Klebsiella, Salmonella, Enterobacter, 174 Escherichi, Pasteurella and Photobacterium) did not exhibit any amplification, and thus, 175 confirmed the specificity of detection. The sensitivity was tested using real-time PCR on 176 serial-dilutions of genomic DNA purified from $V$. parahaemolyticus $t d h+$ and $V$. 177 parahaemolyticus trh2+ and exhibited amplification of $t d h$ and trh2 genes at the level of 0.33 $178 \mathrm{pg}$ and of $0.126 \mathrm{pg}$, respectively. Alternatively, unenriched 10-fold serial-dilution of pure 179 cultures of $V$. parahaemolyticus $t d h$ and trh2 exibited a detection level of $1.7510^{2} \mathrm{CFU} / \mathrm{ml}$ 180 and of $410^{2} \mathrm{CFU} / \mathrm{ml}$ with the above primers and probes for $t d h$ and $t r h 2$, respectively. 181 Furthermore, the standards used as controls (PCR-positive control) in these assays were 182 plasmids that were cloned with $t d h$ and trh2 amplicons obtained with the real-time systems. 183 The MPN values were calculated and expressed as above. 
184

185

186

187

188

189

190

191

192

193

194

195

196

197

198

199

200

201

202

203

204

205

206

207

208

209

210

211

212

213

214

215

216

217

\section{Results}

\subsection{Vibrio parahaemolyticus}

Vibrio parahaemolyticus was detected in water samples collected from the three lagoons included in this study during the summer months (September 2006, and June 2007) (Fig. 2). Concentrations varied from 1 to $20 \mathrm{MPN} / \mathrm{l}$ in the Thau lagoon and 1,100 MPN/l and more in the Mauguio and Prévost lagoons. Water temperatures ranged from $20^{\circ} \mathrm{C}$ to $24^{\circ} \mathrm{C}$ in the three lagoons and salinity from 36 to $39.6 \%$ in the Thau and Prévost lagoons; Mauguio had lower salinity, 29.6 \% in September, 2006, and 20 \%o in June, 2007. In January, 2007, culturable $V$. parahaemolyticus was detected only in the Prévost lagoon, but at a concentration 1,000 times lower than during the summer months (0.1 to $1 \mathrm{MPN} / \mathrm{l})$. Water temperatures at the time of sampling were $8{ }^{\circ} \mathrm{C}, 11^{\circ} \mathrm{C}$ and $3{ }^{\circ} \mathrm{C}$ for the Thau, Prévost and Mauguio lagoons, respectively, and salinity was comparable to summer salinities, i.e., 37 \%o, $34 \%$ and $20 \%$, respectively. Except for June, 2007, in Thau, enteropathogenic trh2+ $V$. parahaemolyticus was detected in water samples collected from the three lagoons during the summer in numbers from 20 to more than 1,100 MPN/l. Enteropathogenic $t d h+V$. parahaemolyticus was detected only in water samples collected from Thau lagoon (0.4 MPN/l) and from Mauguio lagoon (11 MPN/l) in September, 2006. However, no enteropathogenic $V$. parahaemolyticus was detected in water samples collected from any of the lagoons during winter sampling (January 2007).

The total number of $V$. parahaemolyticus in all sediment samples collected from the three lagoons varied from 0.04 to $0.4 \mathrm{MPN} / \mathrm{ml}$ in winter (January 2007) and during the summer months, varied from 0.09 to $5 \mathrm{MPN} / \mathrm{ml}, 11$ to $110 \mathrm{MPN} / \mathrm{ml}$ and 11 to $1,100 \mathrm{MPN} / \mathrm{ml}$ in the Thau, Mauguio and Prévost lagoons, respectively. Enteropathogenic trh2+ $V$. parahaemolyticus was detected in sediment samples collected from the Mauguio and Prévost lagoons at concentrations of 0.04 to $0.23 \mathrm{MPN} / \mathrm{ml}$ in winter and 5 to $210 \mathrm{MPN} / \mathrm{ml}$ in summer, but only once in sediment collected from the Thau lagoon (0.9 MPN/ml in September, 2006). Enteropathogenic $t d h+V$. parahaemolyticus was detected only in September, 2006, in sediment samples collected from the Thau and Mauguio lagoons (0.04 MPN/ml).

$V$. parahaemolyticus was consistently detected in shellfish tissue during the warm season (Table 2), with concentrations varying from 9 to $210 \mathrm{MPN} / \mathrm{g}$ of mussels and from 1.5 to $2.1 \mathrm{MPN} / \mathrm{g}$ of clams. While $V$. parahaemolyticus was absent in mussels during the winter, it nevertheless remained detectable in clams $(1.5 \mathrm{MPN} / \mathrm{g})$. The concentration of 
enteropathogenic trh2+ $V$. parahaemolyticus in shellfish tissue was lower than the concentration of total $V$. parahaemolyticus, varying from 0.07 to $9 \mathrm{MPN} / \mathrm{g}$ in mussels collected from the Prévost lagoon and detected only once (0.03 MPN/g) in mussels collected from the Thau lagoon (June 2007). Enteropathogenic trh2+ V. parahaemolyticus was not detected in clams and was absent from shellfish collected in January, 2007. Enteropathogenic $t d h+V$. parahaemolyticus was detected in clams sampled during the summer and winter (from 0.07 to $0.4 \mathrm{MPN} / \mathrm{g}$ ). However, it was detected only once in mussels collected from Thau lagoon in September, 2006 (0.04 MPN/g).

\subsection{Vibrio vulnificus}

Vibrio vulnificus was detected during the warm season in water samples collected from Mauguio lagoon, varying from 40 to more than 1,100 MPN/l, in water samples collected from Thau lagoon in June, 2007, and from Prévost lagoon in September, 2006 (70 MPN/l and approximately 1 MPN/l, respectively) (Fig. 2).

V. vulnificus was not detected in sediment samples collected from Prévost lagoon and was detected in Thau lagoon sediment in June, 2007 (0.4 MPN/ml). The concentration of $V$. vulnificus ranged from 0.07 to more than $110 \mathrm{MPN} / \mathrm{ml}$ during the summer months in Mauguio lagoon sediment samples and was not detected in sediment samples collected from the three lagoons during the winter.

V. vulnificus was not isolated from mussel samples collected from Prévost lagoon (Table 2), but was detected in clams collected from Thau lagoon during the warm months (between 0.04 to $15 \mathrm{MPN} / \mathrm{g}$ ), and in mussels from the same lagoon in June, 2007 (0.04 MPN/g).

\subsection{Vibrio cholerae}

Vibrio cholerae was detected in water samples collected from Mauguio lagoon only during the warm season (concentrations ranging from 20 to $40 \mathrm{MPN} / \mathrm{l}$ ) and from Prévost lagoon in September, 2006 (14 MPN/l) (Fig. 2). It was not detected in water samples collected from Thau lagoon and was detected only in sediment samples from Prévost lagoon in September, 2006 (0.07 MPN/ml). V. cholerae was not detected in shellfish collected from the Thau and Prévost lagoons (Table 2). Isolates from $V$. cholerae-positive APW broth streaked onto TCBS agar were confirmed as $V$. cholerae non-O1/non-O139 (data not shown). 


\section{Discussion}

In this study, V. parahaemolyticus, V. vulnificus, and V. cholerae were detected and enumerated in environmental samples (water, sediment, mussels, and clams) using the MPNPCR method. This method was used because it permits enhanced detection of Vibrio spp. compared to direct plating using selective media, and notably because large samples can be employed (1-liter water samples inoculated in triplicate and $10 \mathrm{ml}$ in triplicate of sediment or shellfish). Furthermore, the MPN-PCR and MPN-real-time PCR methods were selected because they allowed to provide data comparable to those obtained in studies investigating the presence and ecology of Vibrio spp. and pathogenic Vibrio species in seafood and coastal environmental samples from many other parts of the world (Wright et al., 2007; Luan et al., 2008; Blanco-Abad et al., 2009; Vezzulli et al., 2009).

The presence of the three Vibrio spp. pathogenic for humans was either not detected in water samples collected from the Thau, Prévost and Mauguio lagoons or detected at very low concentrations during the winter, while higher concentrations were detected during the summer, confirming results of investigators in the United States (Motes et al., 1998; Pfeffer et al., 2003; Parveen et al., 2008) and Japan (Fukushima and Seki, 2004). These Vibrio spp. have also been detected in European coastal waters, i.e. in France (Hervio-Heath et al., 2002; Robert-Pillot et al., 2004; Deter et al., 2010), Spain (Martinez-Urtaza et al., 2008), Italy (Barbieri et al., 1999), Denmark (Hoi et al., 1998), and Norway (Bauer et al., 2006).

Most of the investigations showed the presence or absence of these bacteria in water samples. However, few studies reported total culturable V. parahaemolyticus, V. vulnificus, and $V$. cholerae. The counts of culturable $V$. vulnificus ranged from $3 \times 10^{4}$ bacteria/l to $2 \times 10^{5}$ bacteria/l in surface waters of Chesapeake Bay (Wright et al., 1996) and from 5 to 19 MPN/l in Danish marine waters (Hoi et al., 1998). Counts of V. parahaemolyticus and V. vulnificus were $9.3 \times 10^{4} \mathrm{MPN} / \mathrm{l}$ in estuarine water samples collected from the Sada River in Japan (Fukushima and Seki, 2004). Concentrations of $V$. cholerae in recreational beach waters of Southern California were $<15$ to $60.9 \mathrm{CFU} /$, with higher concentrations in tributaries up to $4.25 \times 10^{5} \mathrm{CFU} / \mathrm{l}$ (Jiang, 2001). High concentrations of $V$. parahaemolyticus (up to $\left.10^{5} \mathrm{CFU} / \mathrm{l}\right), \mathrm{V}$. vulnificus $\left(10^{4} \mathrm{CFU} / \mathrm{l}\right)$, and $V$. cholerae $\left(2 \times 10^{4} \mathrm{CFU} / \mathrm{l}\right)$ were reported in estuarine waters of Eastern North Carolina during the warmer season and of the Northern Gulf of Mexico (Pfeffer et al., 2003; Zimmerman et al., 2007; Blackwell and Oliver, 2008). Depending on the lagoon sampled, the concentrations were a hundred-fold higher than those reported in this study. 
Temperature has been shown to be the major factor explaining the dynamics of $V$. parahaemolyticus, $V$. vulnificus, and $V$. cholerae in coastal marine ecosystems. Many studies have shown, both experimentally and in situ, that these bacteria enter a viable but non culturable state when water temperatures average less than $15^{\circ} \mathrm{C}$ (Roszak and Colwell, 1987; Colwell and Grimes, 2000). As observed in lagoon water, this phenomenon could explain the absence or presence in very low concentrations of culturable Vibrio in marine coastal waters in the winter. Temperatures above $20^{\circ} \mathrm{C}$ favor growth of Vibrio spp. in seawater (Motes et al., 1998; DePaola et al., 2003; Blackwell and Oliver, 2008). Our results show that temperatures ranging from $20{ }^{\circ} \mathrm{C}$ to $24{ }^{\circ} \mathrm{C}$ during the summer months in the three Mediterranean lagoons studied were correlated with presence of these bacteria.

Salinity is also an important parameter in the dynamics of vibrios in marine systems (Hsieh et al., 2008). Many studies have shown a strong correlation between the presence of these three Vibrio spp. and temperature and salinity (Colwell et al., 1977; Wright et al., 1996; Motes et al., 1998; Jiang, 2001; DePaola et al., 2003; Pfeffer et al., 2003; Randa et al., 2004; Blackwell and Oliver, 2008). The results indicate that a decrease in salinity favors Vibrio growth and proliferation, particularly in brackish waters of estuaries. In this study, the highest concentrations of $V$. parahaemolyticus, $V$. vulnificus, and $V$. cholerae occurred in the Prévost and Mauguio lagoons, both of which have lower salinities than the Thau lagoon. A higher abundance of $V$. vulnificus was observed in the Mauguio lagoon, where salinity ranges from 20 to $29 \%$, confirming that salinity is a strong determinant of $V$. vulnificus abundance and dynamics, as previously reported by Randa et al. (2004).

The ecology of $V$. parahaemolyticus, $V$. vulnificus, and $V$. cholerae in coastal waters is relatively well documented, but information is scarce for sediments. Vibrios are present in sediment during the summer and are either absent or present in low numbers in the winter (DePaola et al., 1994; Pfeffer et al., 2003; Fukushima and Seki, 2004). V. parahaemolyticus and $V$. cholerae were detected at concentrations up to $3 \times 10^{3} \mathrm{MPN} / \mathrm{l}$ and $2 \times 10^{2} \mathrm{MPN} / \mathrm{l}$, respectively, in sediment samples collected from the Spezia Gulf, Italy (Vezzuli et al., 2009). The densities of $V$. parahaemolyticus were one hundred times lower than those reported in this study. $V$. parahaemolyticus and $V$. vulnificus counts in estuarine sediment samples collected from the Sada river in Japan displayed values comparable to those observed in sediment samples from the Prévost and Mauguio lagoons (Fukushima and Seki, 2004). V. vulnificus has also been detected in large numbers in estuarine sediment samples (DePaola et al., 1994; Wright et al., 1996; Hoi et al., 1998). Like estuarine sediments, sediment in the 
320

321

322

323

324

325

326

327

328

329

330

331

332

333

334

335

336

337

338

339

340

341

342

343

344

345

346

347

348

349

350

351

352

353

vibrios. Moreover, $V$. parahaemolyticus and $V$. vulnificus concentrations in the lagoon sediments were, on average, 100 to 1,000 times higher than in the water column. $V$. cholerae was detected less frequently, with equivalent concentrations in sediment and water. Thus, it can be concluded that sediment serves as a reservoir for these Vibrio spp. (DePaola et al., 1994; Fukushima and Seki, 2004; Randa et al., 2004; Vezzulli et al., 2009). V. parahaemolyticus is absent from the water column during the winter season, but it is present in sediment, suggesting that sediment allows at least one subpopulation of these bacteria to survive in the culturable state.

The number of Vibrio spp. in shellfish varies widely and depends on geographical area, environmental conditions, and local parameters. For example, V. parahaemolyticus was detected in concentrations ranging from $<10$ to 12,000 CFU/g in Alabama oysters (DePaola et al., 2003), < 10 to $600 \mathrm{MPN} / \mathrm{g}$ in Chesapeake Bay oysters (Parveen et al., 2008), < 10 to $32 \mathrm{MPN} / \mathrm{g}$ in mussels collected in Spain (Martinez-Urtaza et al., 2008), < 10 to 10,000 CFU/g in oysters from India (Deepanjali et al., 2005), and < 10 to 1,500 MPN/g in New Zealand oysters (Kirs et al., 2011). In oysters from the lagoons of Mandinga (Veracruz), Mexico, the concentrations of $V$. parahaemolyticus ranged from $<3$ to $150 \mathrm{MPN} / \mathrm{g}$ (Reyes-Velazquez et al., 2010), comparable to the numbers in mussels from the Thau and Prévost lagoons (9 to $210 \mathrm{MPN} / \mathrm{g})$.

The number of $V$. parahaemolyticus in shellfish is an indication of the potential risk of gastroenteritis following consumption of shellfish. However, quantification of pathogenic (tdh- or trh-positive) $V$. parahaemolyticus provides perhaps a better estimate of public health risk (Zimmerman et al., 2007). Many studies have detected the two virulence genes (tdh or trh) in coastal water, oyster, and mussel samples and in environmental isolates of $V$. parahaemolyticus (DePaola et al., 2003; Robert-Pillot et al., 2004; Deepanjali et al., 2005; Bauer et al., 2006; Zimmerman et al., 2007; Martinez-Urtaza et al., 2008; Parveen et al., 2008; Deter et al., 2010; Kirs et al., 2011). In general, the percentage of samples that were positive for pathogenic $V$. parahaemolyticus varied according to geographic site, ranging from $<20 \%$ to $100 \%$. However, the percentage of pathogenic $V$. parahaemolyticus strains was $<0.1 \%$ to $15 \%$ of total V. parahaemolyticus (Hervio-Heath et al., 2002; DePaola et al., 2003; Robert-Pillot et al., 2004; Ottaviani et al., 2010; Deter et al., 2010).

Very few data are available on the number of pathogenic $V$. parahaemolyticus in shellfish. The average number of $t d h+V$. parahaemolyticus in oysters collected from two sites in Alabama was 2.7 CFU/g and 1.3 CFU/g, respectively (DePaola et al., 2003). The number of $t d h+V$. parahaemolyticus in oysters in Chesapeake Bay was $10 \mathrm{CFU} / \mathrm{g}$ (Parveen et al., 
354 2008). In the Northern Gulf of Mexico, the number of $t d h+V$. parahaemolyticus and $t r h+V$. 355 parahaemolyticus ranged from < 0.01 to $10 \mathrm{MPN} / \mathrm{g}$ oyster tissue (Zimmerman et al., 2007). 356 The number of pathogenic $V$. parahaemolyticus found in shellfish in this study was slightly 357 lower and reflects the lower concentration of total $V$. parahaemolyticus in shellfish from 358 Mediterranean lagoons.

359 This study is the first to examine simultaneously the concentrations of $V$. vulnificus, $V$. 360 cholerae non-O1/non-O139 and both total and pathogenic (tdh- or trh2+-positive) $V$. 361 parahaemolyticus in water, sediment and shellfish in lagoons.

The three major pathogenic Vibrio spp. for humans were detected in the lagoons and their presence in shellfish mainly eaten raw represents a public health hazard. More 364 information is needed to improve the quantitative risk assessment concerning presence of 365 vibrios in shellfish (WHO, 2011). DePaola et al. (2000) requires the densities $>10$ of $t d h$ 366 and/or trh-positive V. parahaemolyticus be considered unusual. It would be important to 367 determine if any physicochemical condition, other than water temperature, favors an increase 368 in Vibrio populations. Lagoons with lower salinity or showing a significant decrease in salinity due to heavy rainfall need to be studied to determine the effects of both salinity and temperature, combined, on Vibrio population dynamics. Organic matter entering from the watershed to the lagoon during heavy rainfall also may significantly affect the dynamics of

372 these vibrios. In any case, environmental factors certainly play an important role in the

373 dynamics of Vibrio spp. and may well provide preventive measures for management of 374 shellfish safety. 


\section{Acknowledgments}

376

377

This work was supported by funding provided by the French Agency for 378 Environmental and Occupational Health Safety (AFSSET) (Programme Environnement

379 Santé; no. ES-2005-020). Support was provided to RRC by NIH Grant No. 2R01A1039129$380 \quad 11 \mathrm{~A} 2$. 


\section{References}

Aubert, G., Carricajo, A., Vermesch, R., Paul, G., Fournier, J.M., 2001. Isolement de vibrions dans les eaux côtières françaises et infection à V. cholerae non-O1/non-O139. La Presse Médicale 30, 631-633.

Barbieri, E., Falzano, L., Fiorentini, C., Pianetti, A., Baffone, W., Fabbri, A., Matarrese, P., Casiere, A., Katouli, M., Kühn, I., Mollby, R., Bruscolini, F., Donelli, G., 1999. Occurrence, diversity, and pathogenicity of halophilic Vibrio spp. and non-O1 Vibrio cholerae from estuarine waters along the Italian Adriatic coast. Appl. Environ. Microbiol. 65, 2748-2753.

Bauer, A., Ostensvik, O., Florvag, M., Ormen, O., Rorvik, L.M., 2006. Occurrence of Vibrio parahaemolyticus, V. cholerae, and V. vulnificus in Norwegian blue mussels (Mytilus edulis). Appl. Environ. Microbiol. 72, 3058-3061.

Bej, A.K., Patterson, D.P., Brasher, C.W., Vickery, M.C.L., Jones, D.D., Kaysner, C.A., 1999. Detection of total and hemolysin-producing Vibrio parahaemolyticus in shellfish using multiplex PCR amplification of $t l$, $t d h$ and trh. J. Microbiol. Meth. 36, 215-225.

Blackwell, K.D., Oliver, J.D., 2008. Ecology of Vibrio vulnificus, Vibrio cholerae, and Vibrio parahaemolyticus in North Carolina Estuaries. J. Microbiol. 46, 146-153.

Blanco-Abad, V., Ansede-Bermejo, J., Rodriguez-Castro, A., Martinez-Urtaza, J., 2009. Evaluation of different procedures for the optimized detection of Vibrio parahaemolyticus in mussels and environmental samples. Int. J. Food Microbiol. 129, 229-236.

Brasher, C.W., DePaola, A., Jones, D.D., Bej, A.K., 1998. Detection of microbial pathogens in shellfish with multiplex PCR. Current Microbiol. 37, 101-107.

Chun, J., Huq, A., Colwell, R.R., 1999. Analysis of 16S-23S rRNA intergenic spacer regions of Vibrio cholerae and Vibrio mimicus. Appl. Environ. Microbiol. 65, 2202-2208.

Colwell, R.R., Kaper, J., Joseph, S.W., 1977. Vibrio cholerae, Vibrio parahaemolyticus and other vibrios: occurrence and distribution in Chesapeake Bay. Science 198, 394-396.

Colwell, R.R., Grimes, D.J., 2000. Nonculturable microorganisms in the environment. ASM Press, Washington, DC.

Daniels, N.A., MacKinnon, L., Bishop, R., Altekruse, S., Ray, B., Hammond, R.M., Thompson, S., Wilson, S., Bean, N., Griffin, P.M., Slutsker, L., 2000. Vibrio parahaemolyticus infections in the United States, 1973-1998. J. Infect. Dis. 181, 16611666. 
Deepanjali, A., Kumar, H.S., Karunasagar, I., Karunasagar, I., 2005. Seasonal variation in abundance of total and pathogenic Vibrio parahaemolyticus bacteria in oysters along the southwest coast of India. Appl. Environ. Microbiol. 71, 3575-3580.

DePaola, A., Capers, G.M., Alexander, D., 1994. Densities of Vibrio vulnificus in the intestines of fish from the U.S. Gulf Coast. Appl. Environ. Microbiol. 60, 984-988.

DePaola, A., Kaysner, C.A., Bowers, J., Cook, D.W., 2000. Environmental investigations of Vibrio parahaemolyticus in oysters after outbreaks in Washington, Texas, and New York (1997 and 1998). Appl. Environ. Microbiol. 66, 4649-4654.

DePaola, A., Nordstrom, J.L., Bowers, J.C., Wells, J.G., Cook, D.W., 2003. Seasonal abundance of total and pathogenic Vibrio parahaemolyticus in Alabama oysters. Appl. Environ. Microbiol. 69, 1521-1526.

Deter, J., Lozach, S., Veron, A., Chollet, J., Derrien, A., Hervio-Heath, D., 2010. Ecology of pathogenic and non-pathogenic Vibrio parahaemolyticus on the French Atlantic coast. Effects of temperature, salinity, turbidity and chlorophyll a. Environ. Microbiol. 12, 929-937.

Fukushima, H., Seki, R., 2004. Ecology of Vibrio vulnificus and Vibrio parahaemolyticus in brackish environments of the Sada River in Shimane Prefecture, Japan. FEMS Microbiol. Ecol. 48, 221-229.

Geneste, C., Dab, W., Cabanes, P.A., Vaillant, V., Quilici, M.L., Fournier, J.M., 2000. Les vibrioses noncholériques en France: cas identifiés de 1995 à 1998 par le Centre National de Référence. Bulletin Epidémiologie Hebdomadaire 9, 38-40.

Hervio-Heath, D., Colwell, R.R., Derrien, A., Robert-Pillot, A., Fournier, J.M., Pommepuy, M., 2002. Occurrence of pathogenic vibrios in coastal areas of France. J. Appl. Microbiol. 92, 1123-1135.

Hervio-Heath, D., Zidane, M., Le Saux, J.C., Lozach, S., Vaillant, V., Le Guyader, S., Pommepuy, M., 2005. Toxi-infections alimentaires collectives liées à la consommation de moules contaminées par Vibrio parahaemolyticus: enquête environnementale. Bull. Epidemiol. AFSSA 17, 1-2.

Hoi, L., Larsen, J.L., Dalsgaard, I., Dalsgaard, A., 1998. Occurrence of Vibrio vulnificus biotypes in Danish marine environments. Appl. Environ. Microbiol. 64, 7-13.

Hsieh, J.L., Fries, J.S., Noble, R.T., 2008. Dynamics and predictive modeling of Vibrio spp. in the Neuse river estuary, North Carolina, USA. Environ. Microbiol. 10, 57-64.

Iida, T., Park, K.S., Honda, T., 2006. Vibrio parahaemolyticus, in: Thompson, F.L., Austin, B., Swings, J. (eds), Biology of Vibrios. ASM Press, Washington, DC, pp. 341-348. 
Jiang, S.C., 2001. Vibrio cholerae in recreational waters and tributaries of Southern California. Hydrobiologia 460, 157-164.

Kim, Y.B., Okuda, J., Matsumoto, C., Takahashi, N., Hashimoto, S., Nishibuchi, M., 1999. Identification of Vibrio parahaemolyticus strains at the species level by PCR targeted to the toxR Gene. J. Clin. Microbiol. 37, 1173-1177.

Kirs, M., DePaola, A., Fyfe, R., Jones, J.L., Krantz, J., Van Laanen, A., Cotton, D., Castle, M., 2011. A survey of oysters (Crassostrea gigas) in New Zeeland for Vibrio parahaemolyticus and Vibrio vulnificus. Int. J. Food. Microbiol. 147, 149-153.

Luan, X., Chen, J., Liu, Y., Li, Y., Jia, J., Liu, R., Zhang, X.H., 2008. Rapid quantitative detection of Vibrio parahaemolyticus in seafood by MPN-PCR. Curr. Microbiol. 57, 218-221.

Martinez-Urtaza, J., Lozano-Leon, A., Varela-Pet, J., Trinanes, J., Pazos, Y., Garcia-Martin, O., 2008. Environmental determinants of the occurrence and distribution of Vibrio parahaemolyticus in the rias of Galicia, Spain. Appl. Environ. Microbiol. 74, 265-274.

Motes, N.L., De Paola, A., Cook, D.W., Veazey, J.E., Hunsucker, J.C., Gartright, W.E., Blodgett, R.J., Chirtel, S.J., 1998. Influence of water temperature and salinity on Vibrio vulnificus in Northern Gulf and Atlantic coast oysters (Crassostrea virginica). Appl. Environ. Microbiol. 64, 1459-1465.

Oliver, J.D., 2006. Vibrio vulnificus, in: Thompson, F.L., Austin, B., Swings, J. (eds), Biology of Vibrios. ASM Press, Washington, DC, pp. 349-366.

Ottaviani, D., Leoni, F., Rocchegiani, E., Canonico, C., Potenziani, S., Santarelli, S., Masini, L., Mioni, R., Carraturo, A., 2010, Prevalence, serotyping and molecular characterization of Vibrio parahaemolyticus in mussels from Italian growing areas, Adriatic Sea. Environ. Microbiol. Reports 2, 192-197.

Parveen, S., Hettiarachchi, K.A., Bowers, J.C., Jones, J.L., Tamplin, M.L., Mckay, R., Beatty, W., Brohawn, K., DaSilva, L.V., DePaola, A., 2008. Seasonal distribution of total and pathogenic Vibrio parahaemolyticus in Chesapeake Bay oysters and waters. Int. J. Food Microbiol. 128, 354-361.

Pfeffer, C.S., Hite, M.F., Oliver, J.D., 2003. Ecology of Vibrio vulnificus in estuarine waters of eastern North Carolina. Appl. Environ. Microbiol. 69, 3526-3531.

Quilici, M.L., Robert-Pillot, A., Picart, J., Fournier, J.M., 2005. Pandemic Vibrio parahaemolyticus O3:K6 spread, France. Emerg. Infect. Dis. 11, 1148-1149. 
481

482

483

484

485

486

487

488

489

490

491

492

493

494

495

496

497

498

499

500

501

502

503

504

505

506

507

508

509

510

511

512

513

Randa, M.A., Poltz, M.F., Lim, E., 2004. Effects of temperature and salinity on Vibrio vulnificus population dynamics as assessed by quantitative PCR. Appl. Environ. Microbiol. 70, 5469-5476.

Reyes-Velazquez, C., Castaneda-Chavez, M.D., Landeros-Sanchez, C., Galaviz-Villa, I., Lango-Reynoso, F., Minguez-Rodriguez, M.M., Nikolskii-Gavrilov, I., 2010. Pathogenic vibrios in the oyster Crassostrea virginica in the lagoon system of Mandinga, Veracruz, Mexico. Hidrobiologica 20, 238-245.

Rippey, S.R., 1994. Infectious diseases associated with shellfish consumption. Clin. Microbiol. Rev. 4, 419-425.

Robert-Pillot, A., Guenole, A., Lesne, J., Delesmont, R., Fournier, J.M., Quilici, M.L, 2004. Occurrence of the tdh and trh genes in Vibrio parahaemolyticus isolates from waters and raw shellfish collected in two French coastal areas and from seafood imported into France. Int. J. Food Microbiol. 91, 319-325.

Roszak, D. B., Colwell, R. R., 1987. Survival strategies of bacteria in the natural environment. Microbiological Reviews 51, 365-379.

Su, Y.C., Liu, C., 2007. Vibrio parahaemolyticus: a concern of seafood safety. Food Microbiol. 24, 549-558.

Vezzulli, L., Pezzati, E., Moreno, M., Fabiano, M., Pane, L., Pruzzo, C., The VibrioSea Consortium, 2009. Benthic ecology of Vibrio spp. and pathogenic Vibrio species in a coastal Mediterranean environment (La Spezia Gulf, Italy). Microb. Ecol. 58, 808-818.

WHO - World Health Organization, 2011. Risk assessment of Vibrio parahaemolyticus in seafood: interpretative summary and technical report. 200p. Last accessed 11 may 2012. http://www.fao.org/docrep/014/i2225e/i2225e00.pdf.

Wright, A.C., Hill, R.T., Johnson, J.A., Roghman, M.C., Colwell, R.R., Morris, J.G., 1996. Distribution of Vibrio vulnificus in the Chesapeake Bay. Appl. Environ. Microbiol. 62, 717-724.

Wright, A.C., Garrido, V., Debuex, G., Farrell-Evans, M., Mudbidri, A.A., Otwell, W.S., 2007. Evaluation of postharvest-processed oysters by using PCR-based Most-ProbableNumber enumeration of Vibrio vulnificus bacteria. Appl. Environ. Microbiol. 73, 74777481.

Yamamoto, K., Wright, A.C., Kaper, J.B., Morris, J.B., 1990. The cytolysin gene of Vibrio vulnificus: sequence and relationship to the Vibrio cholerae E1 Tor hemolysin gene. Infect. Immun. 58, 2706-2709. 
514 Zimmerman, A.M., DePaola, A., Bowers, J.C., Krantz, J.A., Nordstrom, J.L., Johnson, C.N., 515 Grimes, D.J., 2007. Variability of total and pathogenic Vibrio parahaemolyticus 516 densities in Northern Gulf of Mexico water and oysters. Appl. Environ. Microbiol. 73, 517 7589-7596. 
518 Legends to figures

519

520 Fig. 1. Location of the Thau, Prévost, and Mauguio lagoons on the French Mediterranean 521 coast (Languedoc area).

522 Fig. 2. Numbers of Vibrio parahaemolyticus, $V$. parahaemolyticus trh2+, $V$. 523 parahaemolyticus tdh+, V. vulnificus, and $V$. cholerae in water and sediment samples 524 collected from the Thau, Prévost and Mauguio lagoons. The units are Log MPN/l for water 525 samples and Log MPN/ml for sediment samples. 


\section{Tables}

527 Table 1: Primers used in this study to detect $V$. parahaemolyticus, $V$. vulnificus, and $V$.

528 cholerae in enrichment culture.

\begin{tabular}{|c|c|c|c|}
\hline Vibrio species & $\begin{array}{l}\text { Target genes } \\
\text { region }\end{array}$ & Primer sequences $^{1}$ & Reference \\
\hline \multirow[t]{2}{*}{ V. parahaemolyticus } & \multirow[t]{2}{*}{ toxR } & F-toxRvp: 5'-GTCTTCTGACGCAATCGTTG-3' & Kim et al. (1999) \\
\hline & & R-toxRvp: 5' -ATACGAGTGGTTGCTGTCATG-3' & \\
\hline \multirow[t]{2}{*}{ V. vulnificus } & \multirow[t]{2}{*}{$v v h A$} & L-CTH: 5'-TTCCAACTTCAAACCGAACTATGAC-3' & $\begin{array}{l}\text { Brasher et al. } \\
\text { (1998) }\end{array}$ \\
\hline & & Vvh-R: 5’-TGATTCCAGTCGATGCGAATACG-3' & $\begin{array}{l}\text { Yamamoto et al. } \\
\text { (1990) }\end{array}$ \\
\hline \multirow[t]{2}{*}{ V. cholerae } & $16 S-$ & prVC-F: 5’-TTAAGCSTTTTCRCTGAGAATG-3' & Chun et al. \\
\hline & 23S rRNA & prVCM-R: 5'-AGTCACTTAACCATACAACCCG-3' & (1999) \\
\hline
\end{tabular}

${ }^{1} \mathrm{~S}: \mathrm{G}$ or $\mathrm{C} ; \mathrm{R}: \mathrm{A}$ or $\mathrm{G}$

530

531 Table 2: Concentration (MPN/g of shellfish tissue) of $V$. parahaemolyticus (total, and 532 enteropathogenic, trh2 and $t d h), V$. vulnificus, and $V$. cholerae in mussels and clams collected 533 in September, 2006, January and June, 2007 from Thau and Prévost lagoons.

\begin{tabular}{llccc}
\hline & & September 2006 & January 2007 & June 2007 \\
\hline Total V. parahaemolyticus & Thau lagoon clams & $0.8<2.1<6.3$ & $0.6<1.5<4.1$ & $0.5<1.5<5$ \\
& Thau lagoon mussels & $20<50<240$ & 0 & $10<20<140$ \\
& Prévost lagoon mussels & $3<9<39$ & 0 & $80<210<640$ \\
V. parahaemolyticus trh2+ & Thau lagoon clams & 0 & 0 & 0 \\
& Thau lagoon mussels & 0 & 0 & $0.01<0.03<0.17$ \\
& Prévost lagoon mussels & $3<9<39$ & 0 & $0.02<0.07<0.28$ \\
V. parahaemolyticus $t d h+$ & Thau lagoon clams & $0.02<0.07<0.28$ & $0.1<0.4<0.21$ & $0.1<0.4<0.21$ \\
& Thau lagoon mussels & $0.01<0.04<0.21$ & 0 & 0 \\
& Prévost lagoon mussels & 0 & 0 & 0 \\
V. vulnificus & Thau lagoon clams & $0.01<0.04<0.21$ & 0 & $6<15<41$ \\
& Thau lagoon mussels & 0 & 0 & $0.01<0.04<0.21$ \\
& Prévost lagoon mussels & 0 & 0 & 0 \\
& & & & 0 \\
V. cholerae & Thau lagoon clams & 0 & 0 & 0 \\
& Thau lagoon mussels & 0 & 0 & 0 \\
& Prévost lagoon mussels & 0 & 0 & 0 \\
\hline
\end{tabular}


534

535 Figure 1

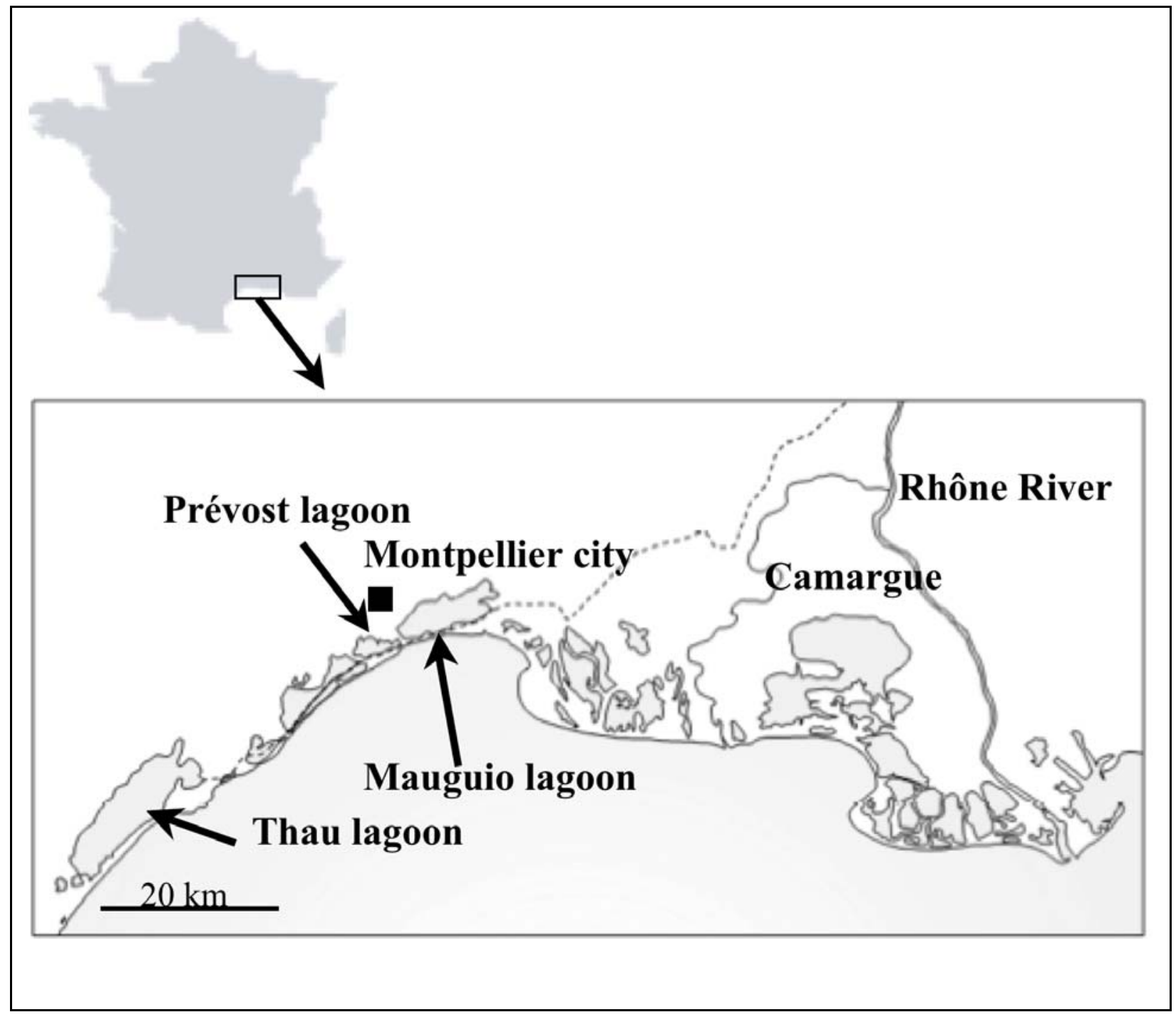




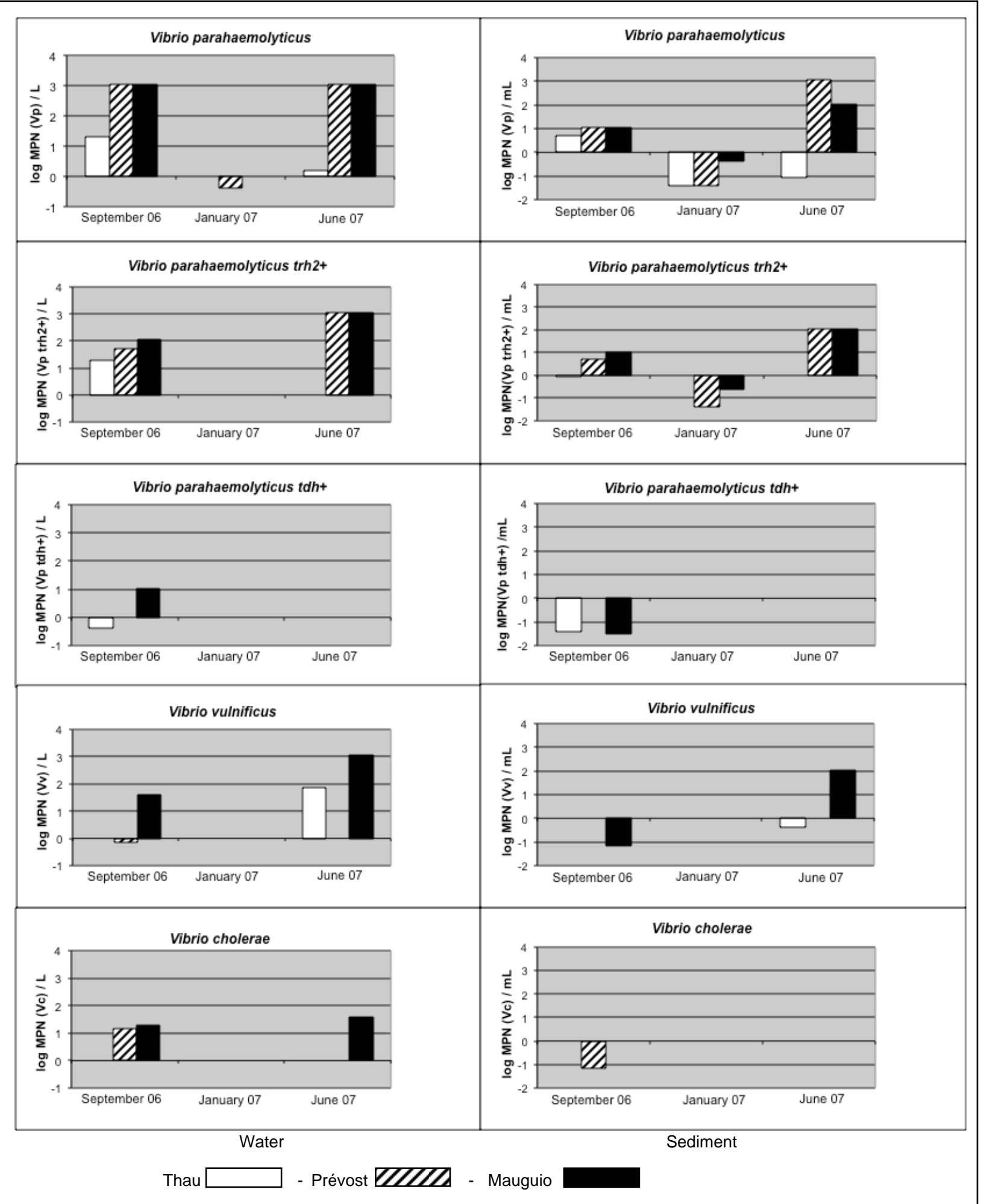

